\title{
The author's strategies of the communicative paradigm in the medieval romance
}

\author{
Valentina Demchenko ${ }^{1}$, Natalia Lutsenko ${ }^{1}$, Olga Gaibaryan $^{2}$, and Yulia Khoroshevskaya ${ }^{3, *}$ \\ ${ }^{1}$ Don State University, Gagarin, 1, Rostov-on-Don, Russia, 344000 \\ ${ }^{2}$ South Federal University, B. Sadovaja str., 352, Rostov-on-Don, Russia, 344000 \\ ${ }^{3}$ Rostov State Transport University, Rostov Rifle Regiment of the People's Militia square, 2, Rostov- \\ on-Don, 344038
}

\begin{abstract}
The research is devoted to the study of the actualization of meanings in a literary text. The study is based on the material of a medieval novel. The subject of the study was the corpus of texts of chivalric novels. In the aggregate, the study of (linguistic-rhetorical) works. The analysis was carried out from the position of studying the author's strategy of influencing the reader in order to have a certain attitude to the hero or plot of the work. The author's influencing strategy in novels is conceptually different from the strategies in works of other genres. The fact that in the works of different authors, united by one image of the main character, use similar elements of influence on the reader, which indicates a special perception of the image of the main character in the minds of people of the XII-XV centuries. This perception is formed both from the totality of literary techniques that pass from work to work, and at the level of linguistic means.
\end{abstract}

\section{Introduction}

The study of the author's strategies involves the study of both the author's attitude to the reader and the results of the reader's perception, his reaction to the work. According to N.N. Pelevina [1], the existing types of the author's strategy combine linguistic and literary devices, and therefore should be considered precisely from a philological point of view as an inseparable unity of two components of humanitarian knowledge [2-4]

The purpose of the research is to study the author's strategies of the medieval chivalric romance. The material for this study was the corpus of medieval chivalric romances.

To achieve this purpose, the following tasks were solved:

- determination of the genre specifics of the medieval chivalric romance;

- general aspects of the plot genesis of a medieval chivalric romance;

- determination of the meaningful nuances of the author's devices - the author's influencing strategy.

The concept of the author's strategy is currently in the process of interdisciplinary synthesis. It correlates with both literary studies [5-6] and linguistic pragmatics.

\footnotetext{
*Corresponding author: georgy-2583@yandex.ru
} 
From the point of view of linguopragmatics, the motivating component of the author's speech influence on the reader is studied in detail.

From the point of view of literature studies, it is the use of linguistic means in their expressive and motivating ability to convey the author's intention, create an image, and influence the reader's inner perception [1].

\section{Materials and methods}

The genre originality of the chivalric romance allows the study of the multifaceted structure of the work, in which the author's intention is realized by linguistic and literary means. The genre of the medieval chivalric romance includes a wide range of fictional texts - from the works of Chrétien de Trois and Wolfram von Eschenbach to Amadis and even Don Quixote.

The chivalric romance has close ties with the folkloric "magic" fairy tale, from which it borrows many compositional and expressive features. For our research, this aspect is of fundamental importance, since it allows us to consider the genesis of the development of author's strategies that originate in folk art.

In our opinion, the tendentious source of the chivalric romance was the romanized Celtic, and later the East and North Germanic folk tales. References to such legends can be seen, for example, in The Honeysuckle by lais of Marie de France. The short narration develops part of the plot of the Celtic folk tales of Tristan and Isolde.

The symbolism of lais borrows almost entirely from traditional Celtic mythological and folklore symbols. For example:

Meanwhile, he cut down and squared

A hazel branch. When it was pared,

He signed it, using his knife to write,

And placed the signal well in sight.

Cut off from the one he loved, for they

Were like the honeysuckle vine,

Which around a hazel tree will twine,

Holding the trunk as in a fist

And climbing until its tendrils twist

Around the top and hold it fast.

Together tree and vine will last.

But then, if anyone should pry

The vine away, they both will die.

"My love, we're like that vine and tree;

I'll die without you, you without me" [7].

Honeysuckle and hazel symbolize Celtic mythological images of animated nature, still preserved in the minds of average people in the 12th century [8]. The sacred meaning of written graphics ("Without words, Tristram speaks in it"), where each letter had a hidden meaning, was also familiar in the Middle Ages.

Despite the Christianization and Germanization of the population of Gaul, which turned into France, Celtic folklore elements are preserved in French folklore and literature. Germanic, Celtic and pre-Christian Roman folklore and mythological symbols merged and transformed into legends, a hidden figurative language accessible to anyone - from a peasant to a signor. The medieval man in many respects still retain a mythological type of thinking, and the strategy of the author of a chivalric romance is to address the reader's consciousness through intuitively perceived images [7-9].

The legend of Tristan in the form of folk tales was familiar to many. Wrapped in the canonical form of chivalric poetry, it acquired a melodic and rhythmic component. The 
rhythm and poetry of the syllable, the selection of images that echoed the images of the fairy tale familiar to the reader, fascinated him, adding to the popularity and relevance of the authors (fig.1).

That is why the story of Tristan and Isolde enjoyed a certain popularity, being repeated and retold right up to Modern Times.

We see the characteristic features of the successive literary devices in other chivalric romances, in which the author's influence on the reader is realized as a continuation of the folklore tradition, actualized by medieval rhetorical devices. The hero of the Roman de la Rose must pass tests and prove his right to possess the Rose. In the finale of the novel, the poet rips off the Rose and wakes up: he dreamed of everything he had experienced in a dream.

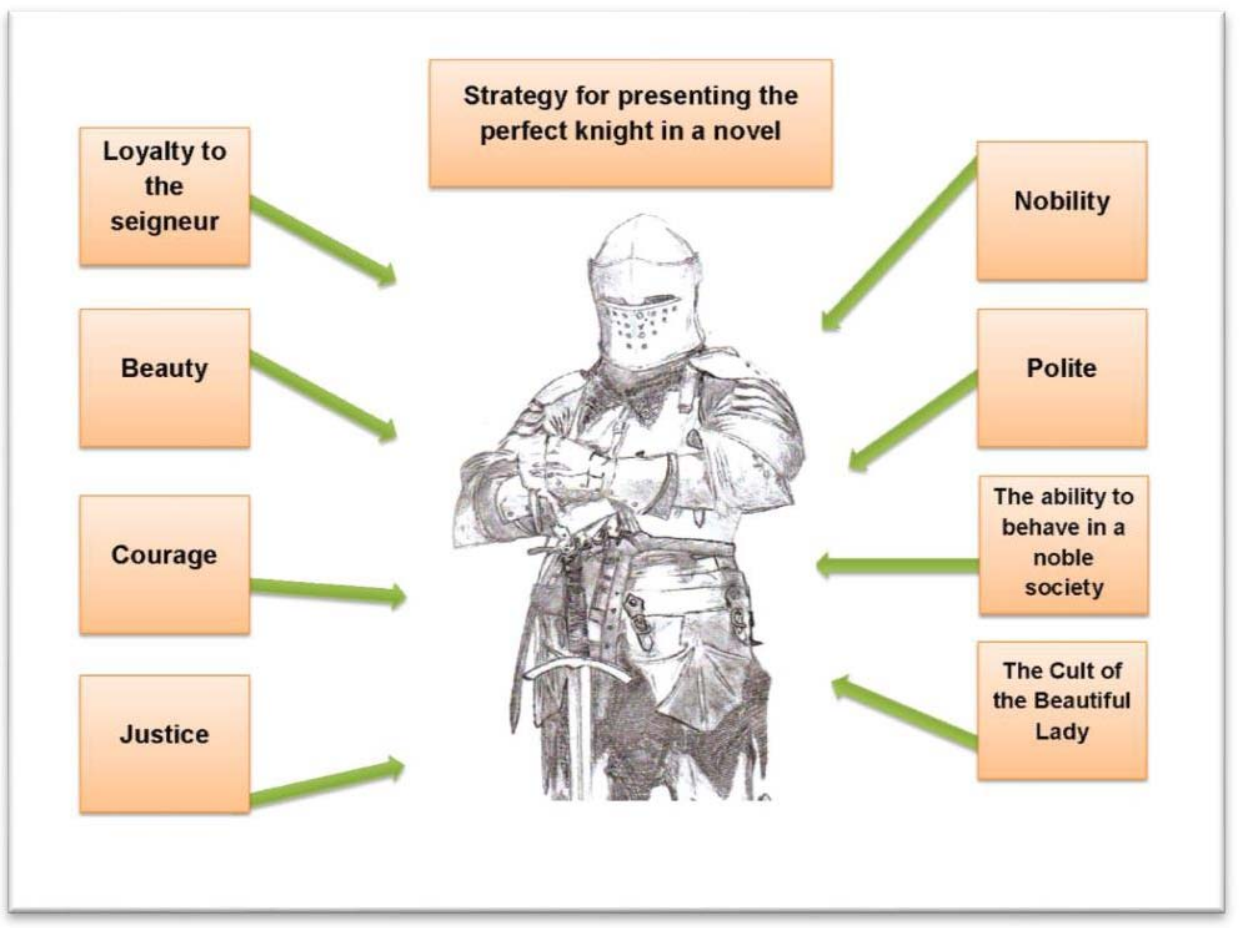

Fig. 1. Strategy for presenting the perfect Knight. Author's development.

The allegory of the garden in the medieval novel tells, in fact, about fostering the soul and feelings. This work was very widespread and caused a number of imitations in preRenaissance and Renaissance literature (attributed to Dante's Il Fiore, The Amorous Vision by Boccaccio, the description of the garden in the Third Day of the Decameron, Triumphs by Petrarch, etc.). We can find a fabulous interpretation of the garden in the Middle High German poem "Rosengarten": the garden of the dwarf Laurin, where he hides the abducted beauty Similda, is surrounded by a silk thread and threatens the knight who dares to cross it by cutting off his arms and legs [9, p. 137].

There is also the image of the garden in the chivalric romance. However, more universal for this genre is another motive that is important for us - the motive of leaving our beloved in the name of fulfilling our duty. The theme of "leaving" in the chivalric romance becomes a prominent theme that forms the plot. The main moral alternative of the hero of the chivalric romance is love for the Lady and the feat of chivalry. These sides of the alternative do not always conflict. The hero performs chivalry deeds in the name of his 
Lady and in order to earn her favor. Courtly love inspires the knight for heroic deeds, without it the knight has no incentive for heroism, "without love there is no chivalry at all" $[10$, p. 118]. At the same time, a moral problem is clearly expressed in the chivalric romance: how the perfect knight should behave in life. Chrétien de Troyes (12th century) was especially sensitive to this philosophical and moral problem. The poet is familiar with the name of this author and his novels from translations into modern French made by Gaston Paris [I], and from his own monograph on medieval French literature [12], which appear in the catalog of Blok's library [8, p. 391]. In his novels, Chrétien gave options for chivalrous behavior, often directly opposite, mutually contradicting, and thus polemicized with himself comprehending the dialectic of human character and life.

In the novel Erec and Enida the hero forgets about the exploits near his young wife, while in the novel Yvain, the Knight of the Lion the hero, carried away by exploits, forgets about the agreed date of returning home, where Laudine is waiting for him. Sometimes, even within the framework of one novel, Chrétien de Troyes presents different approaches to the problem of love and duty. Enida herself reminds her husband, forgotten in the bliss of marriage life, of his chivalrous vocation and, in order not to be separated, goes with him to meet dangers and glory. Along the way, we notice that the chivalric romance reflected one very important feature of medieval way of thinking: traveling associated with overcoming obstacles, the manifestation of fearlessness and will, was perceived as a path of moral improvement, as "movement along the scale of moral values" [13, p. 118]. So, the path and the heroic deed are the moral growth of the hero, rest is a stop in development[14-15].

In the finale of the novel Erec and Enida there is an episode that offers a different version of the knight's behavior than in the story of the protagonist: not a path and moral improvement, but a love captivity that turns into stagnation, degradation and final shame. It is significant that in this episode the traditional image of an enchanted garden appears. Erec must fight the knight who guards the beautiful garden of his beloved and who has the glory of the invincible. The hero defeats the guardian of the garden and thereby removes his spell. The knight of the garden, long languishing in captivity of his love, is glad that the liberation has come. Enida, a sensible wife, who realized in time that the most important thing for a knight is duty to society and herself and who did not allow her husband's shame, with sisterly participation admonishes the mistress of the garden in order to help her find peace of mind and understand that it is necessary to let go of her beloved in order to keep him knight dignity. The duty of the wife is to inspire the beloved for the deeds that he will perform in her honor.

\section{Results}

Studying the genesis of the development of the author's strategies of these works, we see how the devices for the influence of authors on the reader have changed and become more complex. The first thing to highlight is the existence of some "ancient lists" of the legend, which are independently mentioned by the authors of the earliest adaptations. For example, Marie de France directly says:

This lai, a favorite of mine,

Was named for the honeysuckle vine

And written to commemorate

The incident which I'll relate.

Many times I've had the chance

To hear or read the old romance

Of Tristan and the queen, who were

So true to love and to each other

And who, for their love, were sorely tried 
Until, on a single day, they died.

Его (the legend of Tristan and Isolde - the authors' note)

The presence of the primary source emphasizes the traditional character, the authority of the text, which was important for the literary tradition of the Middle Ages, where references to a precedent played a special positioning role in relation to the author on the part of the reader. However, over time, references to ancient sources disappear from the texts of the novels and their plot begins to be presented as taking place in the relatively recent past, i.e. at the standard of living of two or three generations of the author's predecessors. The rejuvenation of the plot was a response to the emerging tendency towards the romanticizing of chivalry, which appeared at the end of the 13th-14th centuries. This trend is a clear manifestation of the change in the author's strategy in response to a change in the reader's priorities while maintaining a popular narrative.

\section{Discussion}

The second feature is the atypical character of the hero. The chivalric romance was closely related to the canonical image of the Knight's code. Valor, loyalty to the suzerain, contempt for personal weaknesses, masculinity and some severity in behavior were required from the knight. Tristan is strikingly different from this image. Where the canonical knight had to sacrifice the forbidden attraction to the chosen one of the suzerain and remain faithful to the vassal oath, from the point of view of the canon, Tristan chooses love for Isolde. Instead of harsh laconicism, he talks a lot about his feelings and experiences, and his language is distinguished by lyricism and emphasized sensuality. Where the traditional hero of a chivalric romance demonstrates contempt for wounds and fatigue, Tristan experiences suffering and overcomes pain and hardship. The image of Tristan is extremely realistic for his era. The authors of the novels show not an ideal hero, but a person who has an incredible freedom of self-expression for the era. This is what the reader wants to see. The rigid framework of the social roles of the medieval world did not allow a person to give free rein to sensuality, limited freedom in the realization of personality.

Social roles in the medieval world were extremely tough, in everyday life they had little opportunity to live in accordance with their aspirations and experiences. The dream in the form of novels about Tristan and Isolde to some extent compensated for the need for a person's sensual self-expression of that era.

At the linguistic level, Tristan's personality manifests itself in the choice of a complicated metaphorical language, saturated with epithets, comparisons, descriptions, hyperboles. [5] Epithets are strung on top of each other, metaphors are linked to each other, forming a complex symbolic context of the hero's inner world. For example, in Gottfried of Strasbourg's version, Tristan exclaims:

Isot ma drüe, Isot m'amie,

En vus ma mort, en vus ma vie.

Izot, I appeal to you,

You are my death, you are my life (translated by V. Shakunov)

For the era of G. Strasbourg (1150-1200s), the concentration of life and death in a beloved, moreover, someone else's wife, is going beyond the possible. For the religious context of the era, the praise of a woman in this way was only possible in the address of the Virgin Mary. Here the reader sees a completely unambiguous reference to the hero's "fury", which broke with the norms of the familiar world.

Here hyperbole shows not only the hero's fearlessness - traditional for the epic - but also his extreme self-confidence. For a medieval man, a hundred "knights" (in the original professional warriors) is quite comparable to the army of Genghis Khan. Such forces cannot be defeated by anyone, but Tristan is given strength by his love for his chosen one. 
An important element that emphasizes the atypical character of the hero is the metamorphosis of his image. Time after time Tristan returns to the same place in the artistic world of the novel or to the same characters, but each time his appearance changes more and more, becoming unrecognizable. The authors of the works show the reader how changeable the essence of a hero obsessed with passion is, how he is reborn internally and externally as the plot develops [11-13].

In the novel Tristan by Eilhart von Oberg (end of the 12th century), the episode of the return is repeated five times. If for the first time Tristan is lost among the courtiers of King Arthur and remains unnoticed by King Mark, but retains his appearance, then for the fifth time Tristan, wounded in battle, loses his usual beauty. It is this transformation that allows him to be with Isolde for the longest time. Here the author shows the fundamental difference between Tristan and the canonical knights of medieval novels. The knight of the medieval romance is always handsome. His physical beauty is a reflection of his beautiful spirit, and if a knight loses his beauty, then, according to tradition, this means his moral decline [14,15]. Accordingly, the lady of the knight rejects him if he changed his appearance other than through a simple disguise. Tristan, on the other hand, enjoys Isolde's favor, despite his injury. His status as a "handsome knight" has nothing to do with his physical form

\section{Conclusion}

In conclusion, we note that all the artistic devices and means of linguistic expression considered in the article implement communicative-pragmatic strategies in poetic and social discourses. They are aimed at shaping the reader's image of an atypical hero of a chivalric romance: extremely realistic by the standards of the era, capable of going beyond social boundaries, independent of the conventions of the canon in the ideological and meaningful message of the author's work. The author's effective strategy in the novels about Tristan and Isolde is conceptually different from the strategies in the works of the same genre. The fact that in the works of different authors, united by one image of the protagonist, similar elements of influence on the reader are used, speaks of a special perception of the image of Tristan in the minds of people of the XII-XV centuries. This perception is formed both from the totality of literary devices passing from work to work, and at the level of linguistic means. In this regard, the works about Tristan and Isolde are of particular importance for the study of the medieval chivalric romance in general.

\section{References}

1. B. Braithwaite, Language 95(1), e161-e187 (2019) doi:10.1353/lan.2019.0025

2. G. Hogan-Brun, B. Palgrave, Macmillan O'Rourke, London, 451-480 (2019) doi:10.1057/978-1-137-54066-9

3. J.J. De Meulder, M. Murray, Lang. Probl. Lang. Plann. 41(2), 136-158 (2017) doi:10.1075/lplp.41.2.04dem

4. S.A. Goico, Sign Lang. Stud. 19(3), 348-374 (2019) doi:10.1353/sls.2019.0001

5. M.A. Tamarkin, A.N. Isaev, E.V. Murugova, V.I. Butenko, MATEC Web of Conf. (2018) doi:10.1051/matecconf/201822601025

6. A. Kusters, M. Spotti, R. Swanwick, E. Tapio Int. J. Multiling. 14(3), 219-232 (2017) doi:10.1080/14790718.2017.1321651 
7. S.V. Pervukhina, O.A. Evtouchenko, L.Iu. Kotliarenko, M.P. Churikov, SHS Web of Conferences. Curr. Iss. Mod. Ling. Hum, 232-244 (2020) doi: 10.1051/shsconf/20208801013

8. T.B. Mikheeva, E.V. Murugova, SHS Web of Conf (2019) doi.org/10.1051/shsconf/20197007003

9. W.C. Hall, L.L. Levin, M.L. Anderson, Soc. Psychiatr. Psychiatr. Epidemiol. 52, 761776 (2017) doi:10.1007/s00127-017-1351-7

10. E. Hoffmann-Dilloway, Lang. Soc. 40, 285-306 (2011) doi:10.1017/S0047404511000194

11. O. Gaibaryan, G. Myasischev, ICTPPFMS 2018, 14-18 (2018) doi:10.2991/ictppfms18.2018.4

12. E.V. Murugova, EpSBS, 416-425 (2018) doi:10.15405/epsbs.2018.04.02.59

13. S. Pervukhina, V. Demchenko, E3S Web of Conf. (ITSE 2020), doi:10.1051/e3sconf/202021018033

14. R.J. Jones, D. Cunliffe, Z.R. Honeycutt, Multiling. Multicult. Dev. 34(7), 653-671 (2013) doi:10.1080/01434632.2013.812096

15. A. Kornai, PloS One 8(10), e77056 (2013) doi:10.1371/journal.pone.0077056 